\title{
EFEKTIVITAS PENGGUNAAN TEKNIK TOKEN EKONOMI TERHADAP PERILAKU PROKRASTINASI AKADEMIK MAHASISWA PROGRAM STUDI PSIKOLOGI FKIK UNIVERSITAS JAMBI
}

\author{
TOKEN ECONOMY EFFECTIVITY TOWARDS ACADEMIC \\ PROCRASTINATION BEHAVIOR AMONG PSYCHOLOGY STUDENTS OF \\ MEDICAL AND HEALTH SCIENCE FACULTY, UNIVERSITY OF JAMBI
}

Oleh:

Khuzaimah*)

\begin{abstract}
ABSTRAK
Penelitian ini bertujuan untuk mengetahui efektivitas penggunaan teknik token ekonomi terhadap perilaku prokrastinasi mahasiswa Program Studi Psikologi FKIK Universitas Jambi.Penelitian menggunakan metode eksperimental-kuasi dengan desain one-group pretest-posttest. Penelitian dilakukan di Prodi Psikologi FKIK Universitas Jambi, dengan jumlah subjek sebanyak 46 mahasiswa.Penelitian menggunakan skala perilaku prokrastinasi akademik.Uji validitas data menggunakan teknik korelasi product moment, sedangkan uji reliabilitas menggunakan teknik koefisien alpha berstrarta. Hasil try out alat ukur menunjukkan bahwa skala perilaku prokrastinasi akademik memiliki skor validitas yang bergerak dari 0,284 sampai 0,782 dengan 30 butir soal pernyataan yang valid dengan nilai reliabilitas 0,82. Analisis data penelitian ini menggunakan teknik paired data t-test.Hasil penelitian menunjukkan terdapat perbedaan perilaku prokrastinasi akademik mahasiswa sebelum dan sesudah diberikan token ekonomi dengan nilai sig. 0,047. Perbedaan signifikan 0,007 berupa penurunan perilaku prokrastinasi akademik maladaptif mahasiswa sebelum dan sesudah diberikan token ekonomi, dan terdapat pengurangan mean sebesar 2,58. Tidak ditemukan perbedaan perilaku prokrastinasi adaptif dan nonprokrastinator pada mahasiswa. Perbedaan perilaku ditunjukkan lebih signifikan pada prokrastinasi maladaptif dengan signifikan 5\% $p=0,007 \quad(p<0,05)$. Penurunan ini dikarenakan adanya nilai sebagai reward yang dihasilkan jika mengumpulkan tugas tepat waktu dan mendapatkan token.
\end{abstract}

Kata Kunci: Mahasiswa, Prokrastinasi Akademik, Token Ekonomi

\section{ABSTRACT}

The purpose of this study was to find out the effectivity of token economy to modify procrastination behavior in Universitas Jambi psychology students. This research used academic procrastination scale as the measurement tools. The research took place in Program Studi Psikologi Fakultas Kedokteran dan Ilmu Kesehatan Universitas Jambi with the amount of 46 students in one sample group.Test the validity of data using product moment correlation technique, while reliability test using alpha stratified technique.The results of try out measuring tools show that academic procrastination scale hasa validity score that movesfrom 0.284 to 0.782 with 30 items of valid statements and got a reliability score of 0.82 .

*) Alumni Prodi Psikologi - Universitas Jambi 
Data analysis techniques used paired data t-test analysis technique.the result showed that there is a difference on college students academic procrastination before and after they were given the token economy as a reward with significant value 0,047. Significant difference 0,007 meaning the decreased of maladaptive procrastination behavior after token given. The mean decreased by value of -2,58. There were no difference on academic procrastination behavior adaptive and non-procrastination behavior. Behavior was more significantly decreased on maladaptive academic procrastination with 5\% $p=0,007(p<0,05)$. These decrease was because of point bonus as a reward to students given they complete their tasks before deadline was set, and they got the token.

Keywords: Academic Procrastination, Students, Token Economy

\section{PENDAHULUAN}

Pendidikan merupakan salah satu faktor penting untuk mewujudkan terciptanya sumber daya manusia yang produktif sebagai pelaku pembangunan.Pendidikan merupakan suatu usaha untuk menumbuhkembangkan potensi sumber daya manusia yang bertujuan untuk mencerdaskan kehidupan bangsa (Mujiyati, 2015). Pada pendidikan formal terdapat 3 jenjang pendidikan yaitu; pendidikan dasar yang berbentuk Sekolah Dasar (SD) dan Sekolah Menengah Pertama (SMP), pendidikan menengah berbentuk Sekolah Menengah Atas (SMA) dan Sekolah Menengah Kejuruan (SMK), dan pendidikan tinggi yang merupakan jenjang pendidikan setelah pendidikan menengah yang mencakup program pendidikan diploma, sarjana, magister, spesialis, dan doktor yang diselenggarakan oleh perguruan tinggi (educational statistics in brief, Kemendikbud 2016).

Menurut Undang-Undang Republik Indonesia No. 12 tahun 2012, pada jenjang pendidikan tinggi tersebut seseorang yang mengikuti kegiatan perkuliahan dikenal dengan sebutan mahasiswa.Mahasiswa yang mengikuti perkuliahan di Universitas Jambi memiliki beban dan masa studi untuk menempuh jenjang pendidikan sarjana dengan masa studi 8 (delapan) semester hingga maksimal 14 (empat belas) semester (Prospektus UNJA No.264/J21/PP/2006).Dari rentang waktu masa perkuliahan tersebut mahasiswa dituntut untuk mampu berprestasi dengan optimal, dan selalu dihadapkan dengan tugas akademik maupun nonakademik.Tugas yang banyak, deadline, kepadatan jadwal perkuliahan serta kegiatan non-akademik memerlukan usaha yang optimal agar dapat memenuhi target waktu yang telah ditetapkan (Subekti, 2014).

Mahasiswa dituntut untuk menyeimbangkan antara kewajiban yang harus dilaksanakan selama berkuliah dan aspek lain di kehidupan, seperti interaksi sosial, kesehatan, keluarga, dan sebagainya. Kondisi ini membuat mahasiswa rentan untuk melakukan penundaan, kelambanan, keterlambatan menghadiri kuliah, keterlambatan dalam menyelesaikan tugas, hingga menunda belajar untuk ujian.Perilaku menunda-nunda ini sering disebut dengan istilah prokrastinasi akademik (Subekti, 2014). 
KHUDZAIMAH,Efektivitas Penggunaan Teknik Token Ekonomi Terhadap Perilaku Prokrastinasi Akademik Mahasiswa Program Studi Psikologi FKIK Universitas Jambi

Menurut Schraw, Wadkins, dan Olafson (2007) prokrastinasi akademik dapat berbentuk prokrastinasi adaptif dan prokrastinasi maladaptif. prokrastinasiakademik tidak selalu dianggap memunculkan dampak negatif bagi individu dan bisa berdampak positif maupun menguntungkan merupakan prokrastinasi adaptif. Hal ini dikarenakan prokrastinasi akademik dapat mengurangi kebosanan, meningkatkan efisiensi kerja, dan membuat individu dapat menikmati atau mengerjakan hal lain selain belajar. Prokrastinasi akademik juga dapat menimbulkan rasa kepuasan dan pencapaian yang tinggi karena telah berhasil mengerjakan tugas dengan baik dalam waktu yang singkat.

Sedangkan prokrastinasi maladaptif merupakan keadaan dimana perilaku menyebabkan dampak negatif dan tidak menguntungkan individu. Pada prokrastinator maladaptif, individu merasakan kemalasan, kecemasan dalam melakukan penundaan dan mengerjaan tugas yang sudah mendesak, ketakutan akan kegagalan, dan mementingkan kegiatan lain yang tidak berhubungan dengan pengerjaan tugas (bermain, menonton dsb) yang tidak diiringi dengan kemampuan mengorganisir tugas.

Berdasarkan penelitian Ozer, Demir, dan Ferrari (2009), prokrastinasi akademik yang terjadi di kalangan mahasiswa Turki mencapai 52\%.Persentase jumlah mahasiswa yang melakukan prokrastinasi tersebut cenderung terjadi pada tugas-tugas akademik mereka. Hal tersebut dapat terlihat dari perilaku prokrastinasi yang dilakukan yaitu sebanyak 33\% perilaku menunda dalam belajar untuk ujian, 30\% prokrastinasi terjadi ketika menulis makalah, dan menunda tugas membaca sebelum perkuliahan sebanyak $30 \%$. Penelitian terdahulu menemukan banyak terjadi prokrastinasi akademik seperti Ellis dan Knaus (1977, dalam Solomon dan Rothblum, 1984) yang menemukan prokrastinasi akademik terjadi 95\%, Solomon dan Rothblum (1984) menemukan 46\% adanya perilaku prokrastinasi mahasiswa.

Penelitian yang dilakukan Surijah dan Tjundjing (2007) menemukan dari 295 mahasiswa sebanyak 30,9\% mahasiswa Fakultas Psikologi Universitas Surabaya tergolong sebagai high sampai dengan very high prokrastinator. Penelitian Ozer (2011) dengan sampel siswa SMA, mahasiswa sarjana dan pascasarjana menemukan bahwa mahasiswa sarjana paling banyak melakukan prokrastinasi.Mahasiswa pascasarjana melakukan prokrastinasi dengan angka yang tidak sebesar mahasiswa sarjana. Siswa SMA lebih sedikit melakukan prokrastinasi dibanding mahasiswa sarjana. Data-data penelitian terdahulu diatas membuktikan bahwa prokrastinasi akademik merupakan perilaku nyata yang terjadi dan dilakukan mahasiswa di perguruan tinggi.

Berdasarkan hasil wawancara dengan 10 mahasiswa Program Studi Psikologi, terdapat perilaku prokrastinasi adaptif sebanyak 1 responden, prokrastinasi maladaptif 8 responden, dan non-prokrastinator 1 responden. Alasan-alasan prokrastinasi yang dipaparkan diantara lain ialah kebingungan dengan tugas, belum menemukan sumber bahan, karena tugas yang mudah dan sedikit, kelupaan, takut salah, kurang minat dengan tugas, laptop rusak, kondisi kesehatan, jenuh, ataupun masalah yang ada dirumah responden. Prokrastinasi maladaptif menurut 8 responden memberikan efek kecemasan, rasa bersalah, ketakutan tidak selesainya tugas, menyesal, tertekan, kelelahan dan beban.Prokrastinasi baik 
adaptif maupun maladaptif memberikan rasa penyesalan terhadap tugas yang kurang optimal.Seluruh responden yang melakukan prokrastinasi setuju terhadap pernyataan "jika saja saya mengerjakan tugas dengan baik dan tanpa penundaan, hasil tugas pasti akan lebih baik lagi”.

Penelitian Subekti (2014) mengenai demografi prokrastinasi mahasiswa di Universitas Indonesia menyebutkan bahwa mahasiswa di tingkat tengah keatas lebih melakukan prokrastinasi akademik daripada mahasiswa tahun pertama dan tahun kedua. Perntyataan ini didukung oleh Semb dkk (1979, dalam Solomon dan Rothblum, 1984) yang menyatakan bahwa "freshmen procrastinate the least; sophomore and seniors the most".

Schraw, Wadkins, dan Olafson (2007) mengemukakan penyebab tingkah laku prokrastinasi akademik dapat bersumber dari tiga faktor yaitu diri sendiri: Ketertarikan personal merupakan penyebab paling penting perilaku prokrastinasi yang bersumber dari diri sendiri. Kurang ketertarikan individu terhadap tugas atau pekerjaan diartikan dengan timbulnya perilaku prokrastinasi.Mahasiswa cenderung menunda tugas yang mereka tidak nikmati/sukai. Faktor pengajar: Karakteristik pengajar memiliki peran penting dalam perilaku prokrastinasi mahasiswa. Dosen dengan instruksi pengajaran yang terorganisasi, menyediakan silabus perkuliahan, dengan langkah yang jelas, evaluasi teratur, dan umpan balik evaluasi yang mendetail, dapat meningkatkan perilaku prokrastinasi akademik.Dosen yang terstruktur dengan jelas mempermudah mahasiswa untuk merencanakan prokrastinasi dengan efektif.Selain itu, ekspektasi dosen juga krusial terhadap prokrastinasi akademik. Dosen dengan ekspektasi yang rendah, yang lebih fleksibel terhadap penilaian mahasiswa dan mau bernegosiasi mengenai tenggat waktu pengumpulan tugas akan meningkatkan perilaku prokrastinasi akademik. Dan faktor tugas: Tugas yang dapat menyebabkan prokrastinasi memiliki dua karakteristik; apakah tugas yang diberikan membutuhkan pengetahuan dasar yang luas, dan kesulitan tugas. Tugas yang sulit seperti tugas menulis, menurunkan perilaku prokrastinasi akademik dan meningkatkan kecemasan mahasiswa dibandingkan tugas yang tidak sulit.

Dalam teori behavioristik, perilaku manusia seringkali diatur oleh konsekuensi yang bergantung pada pengkondisian.Pujian, kritik, nilai yang bagus, ataupun uang adalah konsekuensi yang bisa saja meningkatkan atau mengurangi perilaku.Penguatan (reinforcement) merupakan alat untuk mengkondisikan perilaku.Generalized reinforcement merupakan salah satu jenis penguatan terkondisi (conditioned reinforcement) yang memiliki sisi ekonomis yang bisa ditukarkan dengan poin, barang atau jasa. Salah satu aplikasi terpenting dalam menganalisa perilaku ialah menggunakan token sebagai penguatan terkondisi yang umum (generalized conditioned reinforcement). Token ialah benda seperti kepingan, tiket, koin, tanda cek (Pierce, 2004).

Penguatan token atau yang sering juga disebut dengan token ekonomi adalah salah satu teknik modifikasi perilaku dengan cara pemberian satu token/kepingan (atau satu tanda, satu isyarat) sesegera mungkin setiap kali setelah perilaku sasaran muncul. Token/kepingan-kepingan ini nantinya dapat ditukar dengan 
KHUDZAIMAH,Efektivitas Penggunaan Teknik Token Ekonomi Terhadap Perilaku Prokrastinasi Akademik Mahasiswa Program Studi Psikologi FKIK Universitas Jambi

benda atau aktivitas pengukuh lain (back-up reinforcer) yang diinginkan subjek (Purwanto, 2008). Token ekonomi dalam pendidikan merupakan modifikasi perilaku yang didesain untuk menciptakan suasana kelas yang positif dan produktif dengan menggunakan penguatan untuk meningkatkan motivasi ekstrinsik peserta didik.

Penggunaan token ekonomi untuk meningkatkan perilaku belajar telah banyak dilakukan dalam penelitian terdahulu.Dalam hasil penelitian, token ekonomi berhasil mengurangi perilaku belajar yang tidak diinginkan seperti perilaku offtask dan perilaku disruptif (Chevalier, 2012), dan perilaku lekat di sekolah (Hasanah, 2013).selain itu juga token ekonomi berpengaruh meningkatkan perilaku disiplin (Rahmawati, 2015), prestasi belajar (Sari, 2015), dan partisipasi kelas (Boniecki \& Moore, 2003).

Dari variasi temuan mengenai metode penguatan token ekonomi dalam mengubah perilaku belajar yang diinginkan ini lah, peneliti tertarik untuk melakukan penelitian untuk melihat bagaimana efektivitas penggunaan teknik token ekonomi terhadap perilaku prokrastinasi akademik di Program Studi Psikologi Fakultas Kedokteran dan Ilmu Kesehatan Universitas Jambi.

\section{METODE PENELITIAN}

\section{Variabel Penelitian}

Variabel terikat dalam penelitian ini adalah perilaku prokrastinasi akademik, sedangkan variabel bebas adalah token ekonomi.

\section{Subjek Penelitian}

Subjek penelitian ini adalah mahasiswa Program Studi Psikologi FKIK Universitas Jambi dengan kelompok subjek sebanyak 46 mahasiswa.

\section{Metode dan Instrumen Pengumpulan Data}

Metode pengumpulan data penelitian ini menggunakan instrumen skala perilaku prokrastinasi akademik. Uji validitas data menggunakan teknik korelasi product moment, sedangkan uji reliabilitas menggunakan teknik koefisien alpha berstrarta. Hasil try out alat ukur menunjukkan bahwa skala perilaku prokrastinasi akademik memiliki skor validitas yang bergerak dari 0,284 sampai 0,782 dengan 30 butir soal pernyataan yang valid dengan nilai reliabilitas 0,82 .

\section{Metode Analisis Data}

Analisis data dengan mengguakan teknik paired data t-test.

\section{HASIL DAN PEMBAHASAN}

Uji hipotesis dengan teknik paired sample t-testdilakukan sebanyak 4 kali untuk melihat bagaimana perbedaan perilaku prokrastinasi akademik sebelum dan sesudah diberikan token ekonomi kepada mahasiswa Program Studi Psikologi Fakultas Kedokteran dan Kesehatan Universitas Jambi. Uji hipotesis yang pertama dilakukan untuk melihat hasil total dari pretest dan posttest. Didapatkan hasil nilai $\mathrm{t}$ hitung 2,040 $>2,014 \mathrm{t}$ tabel dengan nilai signifikan $\mathrm{P}$ sebesar $0,047<$ 
0,05 maka hipotesis null (H0) ditolak dan hipotesis alternatif diterima. Perilaku prokrastinasi akademik mahasiswa Program Studi Psikologi Fakultas Kedokteran dan Ilmu Kesehatan Universitas Jambi berbeda secara signifikan sebelum dan sesudah diberikan teknik token ekonomi.

Hal ini sejalan dengan penelitian terdahulu dengan variabel yang sama, dilakukan oleh Mujiyati (2015) bahwa penggunaan teknik token ekonomiterbukti efektif mereduksi prokrastinasi akademik mahasiswa, hal ini dikarenakan dalam penerapan teknik token ekonomilebih terfokus pada tingkah laku yang ditujukan kepada individu yang sesuai dengan target yang telah disepakati dengan menggunakan penguatan positif.

Hal ini juga senada dengan menurut Hadi (2005) yang menjelaskan "token ekonomi atau tabungan kepingan merupakan prosedur kombinasi untuk meningkatkan, mengajar, mengurangi dan memelihara berbagai perilaku".Pada teknik token ekonomi, tingkah laku yang diharapkan muncul bisa diperkuat dengan sesuatu yang diinginkan oleh individu, sehingga hasil perilaku yang diharapkan bisa ditukar dengan sesuatu yang diinginkan oleh individu tersebut.

Akan tetapi, penelitian sebelumnya hanya mengukur tingkat prokrastinasi secara keseluruhan. Menurut Schraw, Wadkins dan Olafson, perilaku prokrastinasi akademik memiliki fenomena adaptif dan maladaptif. Keunikan dari penelitian ini ialah komponen yang diukur berbeda antara satu dengan lainnya.Peneliti kemudian melakukan uji $t$ tes terhadap tiap komponen prokrastinasi, yaotu prokrastinasi adaptif, prokrastinasi maladaptif, dan nonprokrastinator.

Berdasarkan hasil dari analisis data uji hipotesis prokrastinasi adaptif, nilai siginifikan sebesar $0,325>0,05$ menandakan tidak ada perbedaan perilaku prokrastinasi akademik sebelum dan sesudah diberikan teknik token ekonomi. Dalam teori Schraw, Wadkins, dan Olafson (2007) prokrastinator adaptif ialah prokrastinasi yang terencana, di organisasikan dengan baik, dan menghasilkan perasaan tertantang maupun semangat ketika mengerjakan tugas di dekat waktu pengumpulan. Hal ini berarti pada mahasiswa Program Studi Psikologi Fakultas Kedokteran dan Kesehatan Universitas Jambi tidak ada beda bagi subjek yang melakukan prokrastinasi akademik.

Berdasarkan hasil dari analisis data uji hipotesis prokrastinasi maladaptif, nilai siginifikan sebesar $0,007<0,05$ menandakan ada perbedaan perilaku prokrastinasi maladaptif mahasiswa sebelum dan sesudah diberikan teknik token ekonomi. mean deskriptif statistik menunjukkan penurunan mean, yaitu 18,10 pada pretest dan 16,69 pada saat posttest. Penurunan rata-rata ini menunjukkan bahwa perbedaan yang terjadi ke arah positif, yaitu teknik ekonomi dapat menurunkan perilaku prokrastinasi akademik maladaptif pada mahasiswa.Perilaku prokrastinasi maladaptif ialah prokrastinasi yang dilakukan dengan alasan kemalasan, penundaan karena bermain, tidak adanya perencanaan serta rasa khawatir dan ada kecemasan yang timbul ketika mengerjakan tugas dalam waktu yang mendesak. 
KHUDZAIMAH,Efektivitas Penggunaan Teknik Token Ekonomi Terhadap Perilaku Prokrastinasi Akademik Mahasiswa Program Studi Psikologi FKIK Universitas Jambi

Akan tetapi hasil ini menimbulkan kesimpulan yang berbalik dari teori Schraw, Wadkins, dan Olafson (2007) yang menyatakan pemberian tambahan nilai atau penilaian tidak berpengaruh terhadap perilaku prokrastinasi akademik dan tidak menjadi insentif/motivasi yang berarti. Hal ini Kebanyakan mahasiswa menganggap mendapatkan nilai $\mathrm{A}$ adalah hal yang mudah jika diinginkan, lagipula tidak terlalu diperhatikan jika mendapat nilai A ataupun tidak. Pendapat ini berbeda dengan hasil penelitian, dikarenakan insentif yang diberikan dalam penukaran token ialah berupa tambahan nilai tugas sebesar 10 poin.

Berdasarkan hasil dari analisis data uji hipotesis prokrastinasi maladaptif, nilai siginifikan sebesar $0,874>0,05$ menandakan tidak ada perbedaan perilaku nonprokrastinator mahasiswa sebelum dan sesudah diberikan teknik token ekonomi. mean deskriptif statistik menunjukkan penurunan mean, yaitu 22,04 pada pretest dan 21,91, rerata mengalami penurunan yang sangat kecil yaitu sebesar 0,13.

Berdasarkan keseluruhan analisis data, menunjukkan adanya perbedaan siginfikan dari sebelum dan sesudah diberikan teknik token ekonomi. Pemisahan analisis data menghasilkan bahwa hanya perilaku prokrastinasi maladaptif yang mengalami penurunan ketika telah diberikan perlakuan, sementara pada prokrastinasi adaptif dan non-prokrastinator tidak ada perbedaan berarti. Pada perubahan maladaptif didapatkan persenan pengaruh token ekonomi sebesar $32 \%$ dalam menurunkan perilaku prokrastinasi akademik maladaptif, sementara 68\% nya dipengaruhi oleh faktor lain. Dikaitkan dengan teori Schraw, Wadkins, dan Olafson (2007) bahwa penyebab prokrastinasi akademik ialah diri sendiri (self), dosen (teacher), dan tugas (task). Sumbangan 68\% diperkirakan merupakan gabungan antara penyebab prokrastinasi akademik yang lain tersebut, seperti self yang berkaitan dengan ketertarikan subjek terhadap tugas, dan kemampuan subjek dalam mengorganisasikan tugas.

Schraw, Wadkins, dan Olafson (2007) menyatakan bahwa ketertarikan personal merupakan penyebab prokrastinasi yang paling banyak yang berkaitan dengan self, dimana kurangnya ketertarikan diartikan sebagai semakin banyaknya prokrastinasi akademik.Mahasiswa cenderung menunda tugas yang dirasa tidak menarik baginya. Dosen (teacher) ialah penyebab yang lain yang mungkin dapat menjadikan timbulnya perilaku prokrastinasi akademik. Dosen tegas cenderung akan memotivasi mahasiswa untuk melaksanakan tugas dikarenakan adanya tuntutan dari dosen tersebut. Sementara dosen dengan toleransi yang tinggi akan semakin meningkatkan perilaku prokrastinasi akademik.

\section{KESIMPULAN}

Berdasarkan penelitian yang dilakukan pada mahasiswa Program Studi Psikologi Fakultas Kedokteran dan Ilmu Kesehatan Universitas Jambi, maka dapat ditarik kesimpulan sebagai berikut: 1) Terdapat perbedaan signifikan terhadap perilaku prokrastinasi akademik mahasiswa Program Studi Psikologi Fakultas Kedokteran dan Ilmu Kesehatan Universitas Jambi sebelum dengan sesudah diberikan teknik token ekonomi dengan nilai signifikan $p=0,047<0,05$. 2) Tidak terdapat perbedaan terhadap perilaku prokrastinasi akademik adaptif dan non-prokrastinator mahasiswa Program Studi Psikologi Fakultas Kedokteran dan 
Ilmu Kesehatan Universitas Jambi sebelum dengan sesudah diberikan teknik token ekonomi. 3) Terdapat perbedaan signifikan terhadap perilaku prokrastinasi akademik maladaptif mahasiswa Program Studi Psikologi Fakultas Kedokteran dan Ilmu Kesehatan Universitas Jambi sebelum dengan sesudah diberikan teknik token ekonomi dengan nilai signifikan $p=0,007<0,05$. Perbedaan menunjukkan kearah positif, dengan nilai mean prokrastinasi adaptif yang menurun sebesar 2,58. Hal ini menunjukkan bahwa token ekonomi memberikan perbedaan berupa dengan menurunnya perilaku prokrastinasi akademik maladaptif.

\section{DAFTAR PUSTAKA}

Aljuhaish, S. F. (2015). The Effectiveness of Behaviourist's Token Economy System on Teaching English as a Second Language at Saudi Schools in Kuala Lumpur. International Journal of Novel Research in Education and Learning, 2(3), 43-49.

Boniecki, K. A., \& Moore, S. (2003). Breaking the Silence: Using a Token Economy to Reinforce Classroom Participation. Teaching of Psychology, $30(3)$.

Chevalier, N. T. (2012). The Token Economy; Reducing the Disruptive and OffTask Behavior. (Tesis, Tidak Dipublikasikan). Amerika.

Hasanah, N. (2013). Terapi Token Ekonomi untuk Mengubah Perilaku Lekat di Sekolah. Jurnal Humanitas, 10(1).

Hussain, I., \& Sultan, S. (2010). Analysis of Procrastination Among University Students. Procedia Social and Behavioral Science, 5, 1897-1904.

Indrijati, H. (2009). Efektivitas Metode Modifikasi Perilaku "Token Economy" dalam Proses Belajar Mengajar Dikelas. Jurnal Psikologi Indonesia , 5(1), 43-54.

Mujiyati. (2015). Mereduksi Prokrastinasi Akademik Mahasiswa Melalui Teknik Token Economy. Jurnal Fokus Konseling, 1(2), 142-150.

Ozer, B. U. (2011). A Cross Sectional Study on Procrastination: Who Procrastinate More? International Conference on Education, Research, and Innovation (p. Vol. 18). Singapore: IACSIT Press.

Ozer, B., Demir, A., \& Ferrari, J. (2009). Exploring Academic Procrastination Among Turkish Students: Possible Gender Differences in Prevalence and Reasons. The Journal of Social Psychology, 149, 241-257.

Periantalo, J. (2015). Penyusunan Skala Psikologi: Asyik, Mudah, dan Bermanfaat. Yogyakarta: Pustaka Pelajar.

Pierce, W. D., \& Cheney, C. D. (2004). Behavior Analysis and Learning (3 ${ }^{\text {rd }}$ edition). New Jersey: Lawrence Erlbaum Associates.

Hadi, S. (2015). Statistik. Yogyakarta: Pustaka Pelajar. 
KHUDZAIMAH,Efektivitas Penggunaan Teknik Token Ekonomi Terhadap Perilaku Prokrastinasi Akademik Mahasiswa Program Studi Psikologi FKIK Universitas Jambi

Pusat Data dan Statistik Pendidikan dan Kebudayaan. (2016). Indonesia Educational Statistics in Brief. Kementerian Pendidikan dan Kebudayaan.

Rahmawati, N.S. (2015). Token Economy Sebagai Upaya Meningkatkan Kedisiplinan Siswa pada Mata Pelajaran Matematika Kelas II SD Baturetno. (Skripsi, Tidak Dipublikasikan). Universitas Negeri Yogyakarta, Indonesia.

Republik Indonesia. (2012, Agustus 27). Undang-Undang Republik Indonesia No. 12 tentang Perguruan Tinggi. Retrieved from http://sipuu.setkab.go.id/PUUdoc/17624/UU0122012_Full.pdf

Sari, F. Y. (2015). Efektivitas Metode Token Ekonomi terhadap Peningkatan Prestasi Belajar Pendidikan Agama Islam pada Kelas V di SDIT Bakti Islami Sleman. (Skripsi,Tidak dipublikasikan). Universitas Islam Negeri Sunan Kalijaga, Indonesia.

Schraw, G., Wadkins, T., \& Olafson, L. (2007). Doing the Things We Do: A Grounded Theory of Academic Procrastination. American Psychological Association Journal of Educational Psychology, 99(1), 12-25.

Seniati, L., Yulianto, A., \& Setiadi, B. N. (2011). Psikologi Eksperimen. Jakarta: PT. Indeks.

Siaputra, I. B. (2010). Temporal Motivation Theory; Best Theory (Yet) to Explain Procrastination. Anima Indonesian Psychological Journal, 25(3), 206-214.

Siregar, S. (2017). Statistik Parametrik untuk Penelitian Kuantitatif. Jakarta: Bumi Aksara.

Solomon, L. J., \& Rothblum, E. D. (1984). Academic Procrastination: Frequency and Cognitive-Behavioral Correlates. American Psychological Association Journal of Counseling Psychology, 31(4), 503-509.

Subekti, S. B. (2014). Perbedaan Perilaku Prokrastinasi Akademik pada Mahasiswa Program Sarjana Universitas Indonesia Berdasarkan Demografi. Skripsi. Jakarta: Fakultas Psikologi Universitas Indonesia.

Sumadi, S. (2014). Metodologi Penelitian. Jakarta: PT. Raja Grafindo Persada.

Surijah, E. A., \& Tjundjing, S. (2017). Mahasiswa Versus Tugas: Prokrastinasi Akademik dan Conscientiousness. Anima Indonesian Psychological Journal, 22(4), 352-374.

Suryabrata, S. (2005). Pengembangan Alat Ukur Psikologis. Yogyakarta: Penerbit Andi.

Universitas Jambi. (2013). Prospektus Universitas Jambi 2013/2014. Jambi: Kampus Unja Mendalo.

Urbina, S. (2004). Essentials of Psychology Testing. New Jersey: John Wiley \& Sons, Inc.

Widhiarso, Wahyu. (2009). Koefisien Reliabilitas pada Pengukuran Kepribadian yang Bersifat Multidimensi. Psikobuana, 1(1), 39-48. 
PSYCHO IDEA, Tahun 15. No.1, Februari 2017 ISSN 1693-1076 